\title{
Instructors' Perceptions and Barriers of Learner-Centered Instruction in English at the University Level
}

\author{
Tha'er Issa Tawalbeh ${ }^{1} \&$ AbdulRahman Awad AlAsmari ${ }^{1}$ \\ 1 English Language Center, Taif University, Taif, Kingdom of Saudi Arabia \\ Correspondence: Tha'er Issa Tawalbeh, English Language Center, Taif University, Hawiyah, Building No. 7000, \\ P.O. Box 888, 21974, Kingdom of Saudi Arabia. Tel: 966-599-234-100. E-mail: anasthaer@hotmail.com
}

Received: February 12, 2015

Accepted: March 11, 2015

Online Published: March 24, 2015

doi:10.5539/hes.v5n2p38

URL: http://dx.doi.org/10.5539/hes.v5n2p38

\begin{abstract}
The present paper aims to examine the instructors' perceptions of learner-centered instruction and possible barriers to implementing this instructional method in teaching English as a Foreign Language (EFL) at the university level in the Saudi Arabian context. To do this, four questions were posed. The first question investigates instructors' perceptions of learner-centered instruction, and the second question examines the barriers that would face EFL instructors while implementing learner-centered instruction when teaching preparatory year students. The third and fourth questions are an attempt to investigate if there are any significant differences in instructors' perceptions at $(\alpha=0.05)$ due to instructors' qualifications and years of experience. The researchers developed a 4-likert scale questionnaire of two main parts: personal and professional-perceptions and barriers. The qualitative part includes an open-ended question for instructors to elaborate on possible barriers that would hinder implementing learner-centered instruction. The results of the first question indicated that instructors have a positive attitude toward learner-centered instruction. They believe that it is an effective way to enhance students' learning. The second question reveals that instructors agree with all the barriers that hinder the implementation of this instructional method except one item related to their attitudes which have been demonstrated as positive in their responses to the first question. The third and fourth questions revealed no significant differences in instructors' perceptions due to qualifications and years of experience which could be due to the institutional and educational context that haven't supported instructors' qualifications and years of experience.
\end{abstract}

Keywords: barriers, English as a foreign language (EFL), learner-centered approach, learner-centered instruction, university level, Saudi Arabia, teacher-centered instruction, teachers' perceptions

\section{Introduction and Theoretical Background}

\subsection{An Overview of Learner-Centeredness}

Over the past few decades, calls have been made toward a shift from traditional methods of teaching English into innovative means of instruction. This shift has manifested a noticeable move from teacher-centered instruction into learner-centered instruction which is supported by the communicative approach of language teaching. These calls have also entailed a move toward active learning where learners are actively involved in the learning process. In order for learning to take place, learners are expected to work independently and they may work in pairs or groups to discuss issues of interest, participate in learning tasks, and negotiate meaning. They need to use the language to communicate, convey messages, and discuss issues of interest. Their role should no longer be as passive recipients of information provided by teachers. Meanwhile, the teacher's role should shift from being the provider of knowledge into that of a facilitator assisting learners to learn and relate learning to real life.

According to learner-centeredness, the instructors' role has evolved from mere delivery of content and control of the learning environment to actively involving learners in creating their own learning. In the learner-centered environment, teachers and learners work together in a stimulating and interactive environment (Mahendra, Bayles, Tomoeda, \& Kim, 2005).

Lee and Chen (2010) pointed out that learner-centered teaching and learning is believed to be further enhanced by positive classroom relationships and by ensuring that the learners' interests are considered. Lee and Chen further maintained that education in Taiwan has witnessed educational reform in curriculum, learning materials 
and methods of teaching. Accordingly, universities adopted the shift from traditional teacher-centered instruction to learner-centered instruction where learners have more control on curriculum, materials and instruction.

Communicative Language Teaching (CLT) stresses the benefit of shift from the teacher-centered classroom to a learner-centered classroom setting. The main difference lies in the role of the teacher and that of the learner. In CLT, the role of the learner is demonstrated in terms of the curriculum which meets learners' needs, the learning tasks that involve learners in communication, and the teacher's role as a facilitator in the communication process (Nunan, 1989). The learner is a communicator; learners interact with others and they are actively involved in negotiation of meaning. As such, learners play an active role in the class and they are responsible for their own learning. (Breen, 1991; Nunan, 1988; Larsen-Freeman, 1986). In contrast, teacher-centered classrooms emphasize transmission of knowledge from the teacher to the learner whose main role is to receive information passively (Adair-Hauck, Donato, \& Gumo, 1994). In this regard, the teacher plays a dominant role being the authority in the classroom. Consequently, interaction becomes minimal (Larsen-Ereeman, 1986; Lörscher, 1986).

\subsection{Learner-Centered Instruction: Effectiveness, Perceptions, and Attitudes}

McCombs and Whistler (1997) pointed out that the learner-centered approach emphasizes the learner's role in the learning process. According to a large body of previous studies, this approach has several characteristics including the following:

- Personalized and customized learning where teachers following this approach have high expectations of all learners and pay attention to what learners bring into the class such as knowledge, skills, attitudes, etc. The approach considers the learners' needs and learning styles. Teachers are also aware of the learners' individual differences. Meanwhile, learners are actively involved in learning (Reigeluth \& Duffy, 2008; DiMar-tino, Clark, \& Wolk, 2003; Reigeluth, 1994, 1999a; McCombs \& Whistler, 1997).

- Social and emotional support where teachers well take care of social and emotional growth by creating safe and positive environment in the classroom, which helps students belong in the class (Reigeluth, 1999a; McCombs \& Whisler, 1997).

- Self-regulation where teachers play the role of facilitators rather than providers of information, which gives learners the opportunity to be responsible for their own learning. This would highly help learners participate and actively engage in learning (Cornelius-White \& Harbaugh, 2009; Weimer, 2002; Reigeluth, 1994; McCombs \& Whisler, 1997).

- Collaborative and authentic learning experiences through which teachers help learners to develop real life skills such as communication, creative and critical thinking skills through authentic learning experiences. Teachers encourage learners to work together to solve problems rather than being passive in the class (Cornelius-White \& Harbaugh, 2009; Bransford, Brown, \& Cocking, 2000; Reigeluth, 1994; McCombs \& Whisler, 1997).

-Assessment for learning where teachers assess learners to promote learning. They continually provide feedback on learners' progress, and help learners develop self-assessment skills (Weimer, 2002; Bransford et al., 2000; McCombs \& Whisler, 1997).

The American Psychological Association Board of Educational Affairs (1997) described the factors that define the learner-centered model. This set of principles emphasizes the role of learning and learner:

- Cognitive and metacognitive factors which focus on the constructive nature of learning and assisting learners to become more aware of their thinking and learning.

- Motivational and affective factors which relate to the influence of emotions and the interest of the learner in learning.

-Developmental and social factors that focus on positive learning relationships in establishing a social context that facilitates learning.

- Individual differences that identify unique individual characteristics that determine effective learning modes for different learners.

Scholars derived the major principles of learner-centered instruction. These principles emphasize the role of the learner being the main agent of learning; the major goal is students' learning; encouragement of teacher-student interaction in which students are actively involved; the teacher's role is that of a facilitator; and the emphasis is how well students learn not the frequency of information transmission (Henson, 2003; McCombs \& Whisler, 1997). 
According to the learner-centered approach, learners have more choice and are afforded more control over learning experiences, which are more active, as opposed to being a passive experience ( $\mathrm{O}^{\prime}$ Neill \& McMahon, 2005). Learners may take an active role in assessing their own learning and that of their peers. This process may require a change in the lecturer's perceptions about their own roles as they gather information about learners learning in order to inform ensuring learner-centered teaching activities (Bayat \& Naicker, 2012).

The environment where learner-centered instruction is experienced is different from the traditional teacher-centered classrooms. In the learning-centered approach, learners play new learning roles and take responsibilities. They go beyond taking notes, listening to teachers teach, and passing exams. Learners take real control over their educational experience and are encouraged to make important choices about what and how they will learn (Doyle, 2008).

Rodriguez and Ponce (2013) argued that developing teaching practices that meet the learner needs requires competent teachers who know how to create a learning environment where learners discover, experience and construct knowledge rather than practicing skills. Rodriguez and Ponce concluded that highly qualified teachers who are able to involve learners in the learning process go beyond mere lecturing. Educational agencies must support participatory learning environments in which teachers help learners utilize research, synthesize and evaluate knowledge.

Learner-centeredness considers learning and the learner in terms of their experiences, backgrounds, interests and needs (McCombs \& Whisler, 1997). Learner-centered instruction is based on learners' individual choices, interests, needs, abilities, learning styles, types of intelligences and educational goals (Weimer, 2002; McCombs \& Whisler, 1997). Building on the knowledge, skills, beliefs and attitudes that learners bring to the school is a basic trait of learner-centered instruction (Weimer, 2002).

Learner-centered education considers the learner as the center of the learning process. It emphasizes individual learners' needs, experiences, backgrounds, talents, interests, and capacities (Brown, 2003; Hewett, 2003). Learners learn best when they are involved as active participants in the learning process, not passive and inactive members who just receive content that is not meaningful to their lives and experiences (Gándara, 2010; Garcia \& Kleifgen, 2010; Olsen \& Romero, 2006; Tomlinson \& McTighe, 2006).

People learn best when they are engaged in the topic and motivated to find new knowledge and skills to use in order to solve everyday problems. The aim of learning then is active exploration, construction, and learning rather than the learner being passive attendant of a lecture and a textbook reader (Norman \& Spohrer, 1996). Learner-centered classrooms include the idea of learning partnership between learners and teachers. This partnership implies that practices promoting positive relationships between teacher and students are crucial for high learner motivation and achievement (McCombs, 2003).

The learner-centered approach derives major attention in terms of considering the development of learners' collaboration, higher-order thinking, and problem-solving skills. In addition, it contributes to increased student motivation and learning. In classrooms, students feel accepted and supported, feel the responsibility for their own learning, and are actively involved in the learning process (Cornelius-White \& Harbaugh, 2009; Bransford et al., 2000; McCombs \&Whisler, 1997; Reigeluth, 1994).

Based on that, the learner-centered classroom implies the notion of active participation. The more learners participate, the more they are active and responsible for their learning. They take initiatives to discuss issues of interest, negotiate meaning, construct knowledge, interact with each other and with the teacher, work collaboratively, think critically and solve problems.

\subsection{Barriers of Implementation}

Previous research has shed light on several barriers that would hinder the implementation of learner-centered instruction. The tremendous workload produced by multiple assessments that aim for a learner-centered approach to learning in huge classes and the inability to provide results timeously, often result in lecturers' maintaining teacher-centered approaches to learning even if they appreciate the benefits of learner-centered approaches (Bayat \& Naicker, 2012).

Jo-An and Reigeluth (2011) discussed several barriers to implementing learner-centered instruction. These include: a) lack of time; b) assessment; c) institutional barriers; d) lack of knowledge about learner-centered instruction; d) subject culture; e) teacher's attitude toward learner-centered instruction (p. 59). They also maintained that lack of funding, limited resources, student behavior, class size, inclusion of severe-needs students, and parents who complain about challenging activities can be seen as other barriers to implementing learner-centered instruction. 
According to the researchers' experience through observing EFL teachers in practice, it has been noticed that many instructors at the university level still play the role of lecturers carrying out the task of teaching regardless how much learning would take place in their classes. The majority of EFL university teachers were found to manifest the teacher-centered instruction where they talk most of the time before students who receive information without playing active roles in the classroom. Instructors' roles lack those practices of learner-centeredness. This might be due to their perceptions of the learner-centered approach, or probably to certain barriers that hinder the implementation of learner-centered instruction. Accordingly, the present paper seeks to examine the instructors' perceptions of EFL instructors of learner-centered instruction and possible barriers that prevent them from carrying out the learner-centered practices when assisting students to learn English in the Preparatory Year Program at the university level.

Related literature discussed various aspects of the learner-centered approach in different contexts. However, the context here is different since this paper aims to investigate the degree of instructors' perceptions of learner-centered instruction and possible barriers to implementing this instructional approach in an EFL context in the Preparatory Year Program (PYP). Examining the instructors' perceptions and barriers of learner-centered instruction may have a direct impact on students' learning. EFL University teachers' perceptions might clarify their needs of competencies related to learner-centeredness, and the barriers would reveal what difficulties would prevent them from implementing learner-centered instruction. This would help decision makers follow up these barriers in their plans of setting the appropriate learning environment.

\subsection{Problem Statement and Objective}

As EFL practioners observing teachers' practices in the classroom, it has been noticed that the majority of EFL instructors' classes are teacher-centered. Instructors play a dominant role in the classroom, minimizing opportunities for learners to interact with each other. Learners rarely have opportunities of active involvement in activities. Most of the time, they are passive recipients of information delivered to them by instructors. In this regard, the teacher plays a dominant role being the authority in the classroom. Consequently, interaction becomes minimal (Larsen-Freeman, 1986; Lörscher, 1986).

This might be due to issues related to the EFL university teachers' perceptions of learner-centered instruction and possible barriers that would hinder the implementation of this instructional method. This research paper aims to investigate the instructors' perceptions of learner-centered instruction and barriers of implementation in the EFL university classrooms in order to identify possible reasons which may hinder students' learning. In the Saudi Arabian context, the common assumption is that a college is seen as an institution whose main role is to provide formal instruction. Teachers deliver 50-minute to 75-minute lectures. Some now see that the mission of our higher education system is not instruction but rather that of producing learning with every student by whatever means work best. This paradigm is usually referred to as the Learning Paradigm (Saulnier, Landry, Longeneccker, \& Wagner et al., 2009).

\subsection{Research Questions}

The present paper seeks to answer the following questions:

(1) What are the EFL university instructors' perceptions of learner-centered instruction in the EFL classroom of the Preparatory Year Program?

(2) What are the possible barriers to implementing learner-centered instruction in the EFL classroom of the Preparatory Year Program?

(3) Are there any statistically significant differences in instructors' perceptions of learner-centered instruction due to their qualifications?

(4) Are there any statistically significant differences in instructors' perceptions of learner-centered instruction due to their years of experience?

\subsection{Significance of the Current Study}

The results of this research paper can be significant to:

-Policy makers at university to follow up the barriers that would hinder the implementation of learner-centered instruction.

- EFL instructors to evaluate their perceptions of learner-centered instruction to see if they need to empower their competencies in this field.

-EFL instructors to share their expertise of learner-centered instruction principles and practices to enhance 
students' active learning and involvement.

- Quality and Development Unit in the English Language Center to develop professional development sessions for instructors to develop their competencies in learner-centered instruction.

\subsection{Definition of Terms}

The following terms will have the associated meanings whenever they appear in the present research paper:

- Learner-centered instruction: teaching techniques followed by EFL instructors that minimize the teacher's role to that of a facilitator and maximize the learner's role to that of an active participant in the learning process.

- Teacher-centered instruction: teaching techniques that give the teacher a dominant role while teaching students who are passive recipients of information delivered to them by teachers.

- Preparatory Year Program: a one-year study program where students should pass fundamental courses in order to specialize in their second year at university.

\section{Review of Related Studies}

Many studies provide evidence that students are motivated to learn and develop more in-depth understanding of content as well as real-world skills in learner-centered environments. They play active roles in the learning process by being active participants in the learning tasks. In addition, they work collaboratively to discuss issues of interest, negotiate meaning, and develop their abilities of creative and critical thinking skills. By doing this, they take responsibility for their own learning. The studies reported in this section are arranged chronologically and reveal the effectiveness of learner-centered instruction, teachers' and students' perceptions toward learner-centered instruction.

\subsection{Effectiveness of Learner-Centered Instruction}

Anton (1999) investigated learner-centered and teacher-centered discourse in interactive exchanges between teachers and learners in the second language classroom. He found that interaction provided opportunities for negotiation, which created a better environment to L2 learning. On the contrary, teacher-centered discourse didn't provide opportunities for negotiation. According to Paris and Combs (2000), learner centeredness demonstrated five domains: the emphasis is on the learner; the teacher's main role is to facilitate learning; the teacher promotes active involvement of learners; the teacher promotes learning through interactive decision making; and the teacher is a reflective, ongoing learner.

Previous studies have also argued that collaborative, mentoring style of teaching improved teaching informational systems development to students compared to a traditional lecture-based style (Wells \& Jones, 2005). In the same study, utilizing small work groups, personal work portfolios, and student-driven classroom experiences were found to be associated with higher grades among students in the more collaborative classrooms. It was also reported that students learned important skills such as collaboration and responsibility for their own learning.

Steckol (2007) examined how using formative assessment as a component of learner-centered teaching enhanced student learning. He utilized one-minute papers to summarize class material and student-generated quizzes. Steckol noted that students in the experimental group of learning-centered section of the class scored significantly better on the final exam than those in the control group. Similarly, learner-centered classrooms positively impacted on the academic performance (Salinas \& Johanna, 2008) and had positive effects on motivation and learning strategies (Cheang, 2009)

Strobel and van Barneveld (2009) compared and contrasted the findings of the meta-analytical research on the effectiveness of problem-based learning, one of the learner-centered approaches. They used a qualitative approach to analyze data. The results indicated that problem based learning is more effective than traditional instruction in terms of performance improvement and students' and teachers' satisfaction. From another perspective, $\mathrm{Li}$ and Sinn (2010) investigated the practicability of implementing a learner-centered approach in teaching argumentative writing to senior secondary ESL learners in Hong Kong. The study followed a quasi-experimental pretest-posttest to collect data. The participants were 60 Secondary Five (Grade 11) ESL students in an evening school in Hong Kong. Findings revealed that the learner-centered approach enhanced learners' motivation and performance in ESL writing.

\subsection{Teachers' and Students' Perceptions of Learner-Centered Instruction}

Several previous studies have investigated perceptions of learner-centered instruction. As for students, Lake (2006) analyzed college students' perceptions of learner-centered educational practices. His findings revealed 
that students' progress toward learner-centered thinking was evident. Students reported that they had more responsibility toward their own learning and satisfaction as they became more actively involved in the learning process. In the same vein, Wohlfarth et al. (2008) found that the learner-centered approach contributed to the graduate students' feeling respected as learners, developed their critical thinking skills, and encouraged their self-directedness. Another study reported that students have positive attitudes toward learner-centered writing.

With regard to teachers' perceptions, Yilmaz (2008) conducted a study to explore social studies teachers' views of learner-centered instruction. He used a qualitative method of semi-structured interviews with the participants. The results showed that the participants had positive attitudes toward learner-centered instruction. Teachers believed that it made instruction engaging, enjoyable, involving, challenging, and relevant to their own learning. In a more recent study, teachers displayed positive perceptions of learner-centered instruction (Jo-An \& Reigeluth, 2011). In the same study, the participating teachers reported that the main barriers to learner-centered instruction were lack of technology, lack of time, and assessment.

In sum, previous research has thoroughly discussed effectiveness, teachers' and students' perceptions toward learner-centered instruction in different subject areas and in English in an ESL context. In present study, the focus is placed on instructor's perceptions toward learner-centered instruction and possible barriers to implementing this method when assisting students to learn English in their first year in an EFL context at the university level. Hence, investigating these perceptions and barriers may contribute to enhancing students' learning, and perhaps elaborate on barriers that hinder learners' progress in learning English.

\section{Method}

In this section, the methodology used to collect and analyze data is discussed. It displays how population and sample of the study were identified, instrument validity and reliability, study procedures, and statistical techniques followed to analyze data.

\subsection{Population and Sample Selection}

The population of the study comprised 180 male and female instructors teaching English for preparatory year students at Taif University in the first semester of the academic year 2014-2015. The survey was sent to all of them. 154 instructors responded to the survey. 10 questionnaires were excluded because of essential information missing from part 1 and part 2 of the questionnaire. So, the total number of respondents was 144, which represents about $75 \%$ of the whole population of the study.

\subsection{Study Instrument}

The researchers used a questionnaire developed by Jo-An and Reigeluth (2011). It has been adapted to cover learner-centered instruction instead of learner-centered approaches. The questionnaire covers two parts: The first is personal, and the second part is professional divided into two sections. The first consists of 10 items covering instructors' perceptions of learner-centered instruction, and the second consists of 8 items eliciting possible barriers to implementing learner-centered instruction. This final part is followed by an open ended question for instructors to elaborate on the barriers. Likert scale of four degrees ( $1=$ agree, $2=$ strongly agree, $3=$ disagree, $4=$ strongly disagree) was used to investigate the degree of instructors' perceptions of learner-centered instruction and their evaluation of the barriers facing them when implementing learner-centered instruction (Appendix A).

\subsection{Instrument Validity and Reliability}

The researchers believe that the instrument is valid as it has been developed by experts in the field. However, seven EFL specialists were asked to check if the items were appropriate and relevant to the context of teaching EFL at Taif University. They suggested that certain items should be deleted to avoid duplication. In order to check reliability, the checklist was distributed to $10 \mathrm{EFL}$ instructors. They were asked to respond to the questionnaire items. It has been distributed to them again after two weeks. The results were analyzed and the correlation coefficient (Pearson) between the previous and post time was 0.90 . The Cronbach alpha reliability for the checklist was .86 .

\subsection{Study Procedures}

Having the official approval of the Preparatory Year Deanship, the researchers had access the study sample and got their agreement to respond to the questionnaire. The researchers checked the questionnaire for validity and reliability. It was then distributed and collected after being filled out by the participants. Finally, the researchers processed the results using the appropriate statistical analysis methods and came up with the findings. Based on the findings, the researchers drew relevant conclusions and recommendations. 


\subsection{Statistical Analysis}

Descriptive statistics were used to answer the first and the second questions related to the instructors' perceptions of learner-centered instruction and barriers to implementing it. To answer the third and fourth questions, one way ANOVA was used to investigate whether or not there were any statistically significant differences at $(\alpha=0.05)$ in instructors' perceptions and possible barriers due to instructors' qualifications and years of experience.

\section{Results and Discussion}

To answer the first question concerning the EFL instructors' perceptions of learner-centered instruction in the EFL classroom of the Preparatory Year Program, Table 1 below shows the means, standard deviation and percentages of the instructors' perceptions of learner-centered instruction as shown in the study questionnaire.

Table 1. Means, standard deviation and percentages of the instructors' perceptions of learner-centered instruction

\begin{tabular}{|c|c|c|c|c|c|}
\hline \multirow{2}{*}{ No. } & \multirow{2}{*}{ Perceptions } & \multirow{2}{*}{ Mean } & \multirow{2}{*}{$\begin{array}{l}\text { Std. } \\
\text { Deviation }\end{array}$} & \multicolumn{2}{|c|}{ Percentage } \\
\hline & & & & Agree & Disagree \\
\hline 1 & $\begin{array}{l}\text { My job is to teach the material. If some students don't } \\
\text { learn it, that is their problem. }\end{array}$ & 3.23 & 0.94 & 12.5 & 87.5 \\
\hline 2 & $\begin{array}{l}\text { Learner-centered approach is incompatible with my } \\
\text { subject area. }\end{array}$ & 2.66 & 0.92 & 19.1 & 81.9 \\
\hline 3 & $\begin{array}{l}\text { Learner-centered approach requires too much work from } \\
\text { me. }\end{array}$ & 2.29 & 1.09 & 46.8 & 54.2 \\
\hline 4 & $\begin{array}{l}\text { Learner-centered approach diminishes the amount of } \\
\text { content I can teach. }\end{array}$ & 2.26 & 1.08 & 47.9 & 52.1 \\
\hline 5 & Learner-centered approach is too time-consuming. & 2.17 & 1.03 & 52.1 & 47.9 \\
\hline 6 & $\begin{array}{l}\text { My students are passive and not always responsible. } \\
\text { They are not ready for learner-centered approach, in } \\
\text { which they take responsibility for their learning. }\end{array}$ & 2.08 & 1.01 & 58.4 & 41.6 \\
\hline 7 & $\begin{array}{l}\text { Learner-centered instruction is challenging but } \\
\text { rewarding. }\end{array}$ & 1.56 & 0.77 & 90.9 & 9.1 \\
\hline 8 & $\begin{array}{l}\text { I have enough knowledge about learner-centered } \\
\text { instruction. }\end{array}$ & 1.53 & 0.85 & 80.6 & 19.4 \\
\hline 9 & I want to learn more about learner-centered instruction. & 1.52 & 0.82 & 87.5 & 12.5 \\
\hline 10 & I am a learner-centered teacher. & 1.56 & 0.84 & 81.3 & 19.7 \\
\hline
\end{tabular}

Data analysis shows that instructors disagree with the first 4 perceptions. However, they agree with the last 6 perceptions. To shed more light on teachers' perceptions, it can be seen that instructors strongly disagree with the first two items. $87.5 \%$ of participants disagree with the point that their job is to teach the material. If some students don't learn it, that is their problem. Also, $81.9 \%$ of participants disagreed with the perception that learner-centered approach is incompatible with their subject area. On the other hand, instructors strongly agree with the last 4 items of perceptions. Between $80 \%-90 \%$ of participants agreed with the points that learner-centered instruction is challenging but rewarding. Respondents reported that they have enough knowledge of learner-centered instruction, but they want to learn more. All in all they believe that they are learner-centered teachers.

It is evident that instructors have a positive attitude toward learner-centered instruction. This is clear in their responses of agreement and disagreement with the questionnaire items from 1-10 displayed in Table 1. They strongly disagree with the first two items. Instructors don't believe that their job is to teach the material, which indicates that they take responsibility for students' learning. Also, they disagree that learner-centered instruction is incompatible with their subject area. This can be explained on the ground that learner-centered instruction is compatible with teaching English as it can be with other subject areas. In addition, instructors strongly agree with the last 4 items. They believe that learner-centered instruction is challenging but rewarding, which can be due to instructors' beliefs that getting students to be actively involved in the learning process, maximizing their 
roles as active participants, and giving them the opportunity to take responsibility for their own learning means a challenge for both the teacher and the student. However, this challenge is turned into opportunities for success as learning-centered instruction will be rewarding in terms of fulfilling the core principles of this method of instruction. Learners will be able to achieve the desired learning outcomes by the end of a course assigned to them. Furthermore, they strongly agree with the points that they have enough knowledge of learner-centered instruction, but they want to learn more about it, which shows their positive tendency toward learner-centered instruction. All in all, instructors believe that they are learner-centered teachers, which reflects their positive attitude toward this instructional method.

To shed more light on instructors' positive responses toward learner-centered instruction, it can be noticed that they disagree with the perception that this method requires too much work from them. This can be explained by considering the fact that the teacher's role is minimized to be a facilitator of students' learning rather than a lecturer who plays the maximum role in the class. They also disagree with the point that learner-centered instruction diminishes the amount of content they can teach. Competent teachers following this method employ the content using a variety of teaching learning strategies and techniques. However, $58.4 \%$ of participants agree with the perception that their students are passive and not always responsible. They are not ready for learner-centered approach, in which they take responsibility for their learning. This might be due to students' attitudes to learning English in general and to learner-centered instruction in specific. It can also be due to the subject culture related to the set of practices and expectations that have grown up around teaching English. In addition, $52.1 \%$ of participants agree with the perception that learner-centered approach is too time-consuming. This perception might be explained on the ground that this method of instruction requires students to play the central role in carrying out the activities in pairs and groups, discussing issues of interest, negotiating meaning, and learning cooperatively, which may take time. This point agrees with their perception that lack of time is a barrier to implementing learner-centered instruction as it will be clarified in discussing the second question below.

In order to answer the second question about the possible barriers to implementing learner-centered instruction in the EFL classroom, the tables below display the means, standard deviation and percentages of instructors' points of view of the barriers hindering the implementation of learner-centered instruction in their classrooms.

Table 2. Means, standard deviation and percentages of instructors' points of view of the barriers

\begin{tabular}{|c|c|c|c|c|c|}
\hline \multirow{2}{*}{ No. } & \multirow{2}{*}{ Perceptions } & \multirow{2}{*}{ Mean } & \multirow{2}{*}{$\begin{array}{l}\text { Std. } \\
\text { Deviation }\end{array}$} & \multicolumn{2}{|c|}{ Percentage } \\
\hline & & & & Agree & Disagree \\
\hline 1 & My attitude toward learner-centered instruction & 2.50 & 1.03 & 37.5 & 62.5 \\
\hline 2 & Lack of time & 2.04 & 1.01 & 57.7 & 42.3 \\
\hline 3 & Seating arrangement (seats are fixed not movable) & 1.92 & .90 & 68.1 & 31.9 \\
\hline 4 & Lack of knowledge about learner-centered instruction & 1.90 & 1.04 & 62.5 & 37.5 \\
\hline 5 & Institutional barriers (schedule, university rules, etc.) & 1.89 & .98 & 63.9 & 36.1 \\
\hline 6 & Students' attitude toward learner-centered instruction & 1.70 & .86 & 77.1 & 22.9 \\
\hline 7 & $\begin{array}{l}\text { Subject culture (the general set of institutionalized } \\
\text { practices and expectations which have grown up around } \\
\text { teaching English) }\end{array}$ & 1.69 & .89 & 72.2 & 27.8 \\
\hline 8 & Crowded classes & 1.63 & .63 & 93.1 & 6.9 \\
\hline
\end{tabular}

According to the percentages displayed in the table above, the instructors demonstrated their disagreement with the first perception. $62.5 \%$ of participants believe that their attitude toward learner-centered instruction is not a barrier to implementing this instructional method in an EFL classroom. However, they showed agreement with the rest of the items expressing possible barriers that would hinder the implementation of learner-centered instruction from their own point of view.

It can be noticed from Table 2 that instructors agree with all the barriers mentioned in the questionnaire items from 11-18 with the exception of the first point related to their attitude toward learner-centered instruction. Instructors don't believe that their attitude is one of the barriers to implementing learner-centered instruction in 
their EFL classroom because as discussed in the first question, they have a positive attitude toward this method of instruction. All the other items are seen as barriers from the instructors' points of view. This could be due to the fact the teaching learning process entails certain challenges that teachers may encounter while teaching English as a foreign language. It can also be claimed that instructors actually encounter daily challenges related to crowded classes, the subject culture in terms of institutionalized set of practices and expectations which have grown up around teaching English, students' attitude toward learner-centered instruction, institutional barriers, lack of training, and seating arrangements in that seats are fixed. In addition, many teachers agree with other barriers to implementing this method of instruction in their responses to the open ended question as reported in the findings section. These barriers either add to or support those mentioned in the questionnaire items from 11-18 in terms of their focus on students' attitudes toward learner-centered instruction or stating facts that reflect the actual situation which includes certain barriers to implementing this method in the EFL classroom.

In addition, the qualitative part of the research paper includes an open-ended question related to more possible barriers not addressed in Table 2 above. Their responses were identified from the most frequent to the lease frequent. These include lack of technology resources (smart board, projector, Data show, and internet facilities), students' demotivation, and students' not getting used to learner-centered instruction in previous educational stages, students' low language proficiency level, and teaching methods in other subject areas that rely on teacher-centered instruction.

Concerning the third and fourth questions which aim to find out if there are any statistically significant differences at $(\alpha \leq 0.05)$ in instructors' perceptions of learner-centered due to their qualifications and years of experience, the tables below show the means and standard deviation, and ANOVA test of the instructors' qualifications and years of experience.

Table 3. Means and standard deviation of instructors' qualifications

\begin{tabular}{llll}
\hline Qualification Category & No. & Mean & Std. Deviation \\
\hline Bachelor & 39 & 2.18 & .43 \\
Bachelor and Diploma & 34 & 1.99 & .37 \\
Master & 68 & 2.11 & .47 \\
PhD & 3 & 2.13 & .40 \\
Total & 144 & 2.10 & .44 \\
\hline
\end{tabular}

Data analysis shows that there are differences in the means of instructors' qualifications. In order to find out whether these differences were statistically significant, one way analysis of variance test was used. Results show that that there are no statistically significant differences in instructors' perceptions of learner-centered instruction due to their qualifications. See Table 4 below.

Table 4. ANOVA test

\begin{tabular}{llllll}
\hline Groups & Sum of Squares & Df & Mean Square & F & Sig \\
\hline Between Groups & .67 & 3 & .225 & & \\
Within Groups & 27.18 & 140 & & 1.160 & .327 \\
Total & 27.86 & 143 & .194 & & \\
\hline
\end{tabular}

Table 5. Means and standard deviation of instructors' years of experience

\begin{tabular}{llll}
\hline Qualification Category & No. & Mean & Std. Deviation \\
\hline Less than 5 years & 33 & 2.01 & .32 \\
From 5 to 10 years & 37 & 2.11 & .41 \\
11 years and more & 74 & 2.14 & .49 \\
Total & 144 & 2.10 & .44 \\
\hline
\end{tabular}


In terms of instructors' years of experience, Table 5 shows that there are differences in the means of instructors' years of experience. One way analysis of variance test was used to measure significance of these differences. The significance value is .368 which is more than $(\alpha \leq 0.05)$. This indicates that there are no statistically significant differences in instructors' perceptions of learner-centered instruction due to their years of experience. See Table 6 below.

Table 6. ANOVA test

\begin{tabular}{llllll}
\hline Groups & Sum of Squares & Df & Mean Square & F & Sig. \\
\hline Between Groups & .39 & 2 & .196 & & \\
Within Groups & 27.47 & 141 & & 1.007 & .368 \\
Total & 27.86 & 143 & & & \\
\hline
\end{tabular}

It is evident that there are no statistically significant differences in instructors' perceptions of learner-centered instruction due to their qualifications and years of experience, it was expected that higher qualifications and longer years of experience may make a difference in the instructors' perceptions of learner-centered instruction. However, the results revealed no significant differences. First, it can be claimed that the institutional and educational context may not have supported qualifications and years of experience to play a significant role in making a difference in the instructors' perceptions toward learner-centered instruction. This might be due to certain institutional barriers of schedule and university rules that require teachers to finish the allocated material within a specified time limit, which entails traditional instructional methodology followed by instructors regardless of their qualifications and years of experience in teaching English as a foreign language. In addition, students' low proficiency language level and crowded classes might have hindered instructors from implementing this instructional method of instruction which maximizes students' role in the learning process.

\section{Conclusions and Recommendations}

The present paper examined the instructors' perceptions of learner-centered instruction and possible barriers to its implementation in EFL university context. It has been concluded that instructors have a positive attitude toward learner-centered instruction. They believe that it is an effective way to enhance students' learning. In addition, instructors agree with all the barriers that hinder the implementation of this instructional method except one item related to their attitudes which have been demonstrated as positive in their responses to the first question. Furthermore, the study revealed that there are no statistically significant differences in instructors' perceptions due to qualifications and years of experience which could be due to the institutional and educational context that haven't supported instructors' qualifications and years of experience.

To sum up, some studies reported in this paper highlighted the fact that students are motivated to learn more in learner-centered environments. They discussed the effectiveness of learner-centered instruction (Anton, 1999; Paris \& Combs, 2000; Wells \& Jones, 2005; Salinas \& Johanna, 2008; Cheang, 2009). In addition, other studies discussed teachers' and students' perceptions toward leaner-centered instruction in an ESL context (Lake, 2006; Wolfharth et al., 2008; Yilmaz, 2008; Lee \& Chen, 2010; Jo-an \& Reighluth, 2011). In this study, the researcher examined instructors' perceptions to learner-centered instruction and possible barriers that would hinder the implementation of this instructional method in an EFL context for students in their preparatory year at Taif University.

Based on the results of the present paper, the researchers have come up with the following recommendations:

(1) Policy makers to follow up the barriers that would hinder the implementation of leaner-centered instruction as they may adversely affect students' learning English in the Preparatory Year Program at Taif University.

(2) Professional development sessions for instructors to discuss their perceptions toward learner-centered instruction and the barriers that would hinder the implementation of learner-centered instruction.

(3) Other studies may be conducted to reveal students' perceptions toward learner-centered instruction and possible challenges that may hinder application.

(4) Other studies may be conducted to further investigate the barriers instructors had in their response to the open-ended question. 


\section{Acknowledgments}

The researchers would like to acknowledge the contribution of the instructors who validated the study instrument and those who responded to the questionnaire. Special thanks also go to the colleagues who assisted in the manuscript preparation.

\section{References}

Adair-Hauck, B., Donato, R., \& Cumo, P. (1994). Using a Whole Language Approach to Teach Grammar. In J. Scbrum, \& E. Clisan (Eds.), Contextualized foreign language instruction K-12 (pp. 90-111). Boston: Heinle.

American Psychological Association Board of Educational Affairs. (1997). Learner-centered psychological principles: A framework for school reform and redesign. Washington, DC: American Psychological Association.

An, Y. J., \& Reigeluth, C. (2011). Creating Technology-Enhanced, Learner-Centered Classrooms: K-12 Teachers' Beliefs, Barriers, and Support Needs. Journal of Digital Learning in Technology Education, 28(2), 54-62. http://dx.doi.org/10.1080/21532974.2011.10784681

Anton, M. (1999). The Discourse of a Learner-Centered Classroom: Sociocultural Perspectives on Teacher-Learner Interaction in the Second-Language Classroom. The Modern Language Journal, 83(3), 303-318. http://dx.doi.org/10.1111/0026-7902.00024

Bayat, A., \& Naicker, V. (2012). Towards a Learner-Centered Approach: Interactive Online Peer Assessment. SAJHE, 26(5), 891-907.

Bransford, J. D., Brown, A. L., \& Cocking, R. R. (2000). How People Learn: Brain, mind, experience, and school. Washington, D.C.: National Academy Press.

Breen, M. (1991). Understanding the Language Teacher. In R. Phillipson, E. Kellerman, L. Selinker, M. S. Smith, \& M. Swain (Eds.), Foreign/second and language pedagogy research (pp. 213-233). Clevedon, England: Multilingual Matters.

Brown, K. L. (2003). From Teacher-Centered to Learner-Centered Curriculum: Improving Learning in Diverse Classrooms. Education, 124(1), 49-54.

Cheang, K. I. (2009). Effects of Learner-Centered Teaching on Motivation and Learning Strategies in a Third-Year Pharmacotherapy Course. American Journal of Pharmaceutical Education, 73(3), 42. http://dx.doi.org/10.5688/aj730342

Cornelius-White, J. H. D., \& Harbaugh, A. P. (2009). Learner-Centered Instruction: Building Relationships for Student Success. Thousand Oaks, CA: Sage.

DiMartino, J., Clark, J., \& Wolk, D. (Eds.). (2003). Personalized Learning: Preparing High School Students to Create their Futures. Lanham, MD: The Scarecrow Press.

Doyle, T. (2008). Helping Students Learn in a Learner-Centered Environment: A Guide to Facilitating Learning in Higher Education. Sterling, VA: Stylus Publishing.

Gándara, P. (2010). Forbidden Language: English Learners and Restrictive Language Policies. New York, NY: Teachers College Press.

Garcia, O., \& Kleifgen, J. A. (2010). Educating Emergent Bilingual: Policies, Programs and Practices for English Language Learners. New York, NY: Teachers College Press.

Henson, K. T. (2003). Foundations for Learner-Centered Education: A Knowledge Base. Education, 124(1), $5-16$.

Hewett, S. M. (2003). Learner-Centered Teacher Preparation: A Mastery of Skills. Education, 124(1), 24-30.

Lake, H. C. (2206). Student Perceptions of Learner-Centered Education. Annual Conference of the Northern Rocky Mountain Education Research Association. Retrieved from http://www.eric.ed.gov/contentdelivery/ servlet/ERICServlet?accno=ED494914

Larsen-Freeman, D. (1986). Techniques and Principles in Language Teaching. New York: Oxford University Press.

Lee, I. Y., \& Tzuching, K. (2010). Learner-Centered Writing: English as a Foreign Language. The International Journal of Learning, 17(6), 231-243.

Li, K. H., \& Sinn, M. C. (2010). Teacher as the Change Agent: Implementation and Impact of a 
Learner-Centered approach in Teaching Argumentative essays to Senior Secondary ESL Learners in Hong Kong. The International Journal of Learning, 17(4), 595-611.

Lörscher, W. (1986). Conversational Structures in the Foreign Language Classroom. In G. Kasper (Ed.), Learning, Teaching, and Communicating in the Foreign Language Classroom (pp. 11-22). Aarhus, Denmark: Aarhus University Press.

Mahendra, N., Bayles, K. A., Tomoeda, C. K., \& Kim, E. S. (2005). Diversity and Learner-Centered Education. ASHA Leader, 10(16), 12-19.

McCombs, B. L. (2003). A Framework for the Redesign of K-12 Education in the Context of Current Education Reform. Theory into Practice, 42(2), 93-101. http://dx.doi.org/10.1207/s15430421tip4202_2

McCombs, B. L., \& Whisler, J. S. (1997). The Learner-Centered Classroom and School: Strategies for Increasing Student Motivation and Achievement. San Francisco: Jossey-Bass.

Norman, D. A., \& Spohrer, J. C. (1996). Learner-Centered Education. Communications of the ACM, 39(4). http://dx.doi.org/10.1145/227210.227215

Nunan, D. (1988). The Learner-Centered Curriculum. Cambridge: Cambridge University Press. http://dx.doi.org/10.1017/CBO9781139524506

Nunan, D. (1989). Designing Tasks for the Communicative Classroom. Cambridge: Cambridge University Press.

O’Neill, G., \& McMahon, T. (2005). Student-Centered Learning: What does it mean for students and lecturers? In G. O'Neill, S. Moore, \& B. McMullin (Eds.), Emerging Issues in the Practice of University Learning and Teaching. Dublin: AISHE. Retrieved from http://www.aishe.org/readings/2005-1

Olsen, L., \& Romero, A. (2006). Knowing our English Learners, Unit 1: Secondary school leadership for English learner success. Oakland, CA: California Tomorrow and Los Angeles County Office of Education.

Paris, C., \& Combs, B. (2000). Teachers' Perspectives on What it Means to be Learner-Centered. Annual Meeting of the American Education of Research Association. Retrieved from $\mathrm{http}: / / \mathrm{www} . e r i c . e d . g o v /$ contentdelivery/servlet/ ERICServlet?accno=ED446070

Reigeluth, C. M. (1994). Envisioning a New System of Education. In C. M. Reigeluth, \& R. J. Garfinkle (Eds.), Systemic change in education (pp. 59-70). Englewood Cliffs, NJ: Educational Technology Publications.

Reigeluth, C. M. (1999a). Visioning Public Education in America. Educational Technology, 39(5), 50-55.

Reigeluth, C. M., \& Duffy, F. M. (2008). The AECT Future Minds Initiative: Transforming America's school systems. Educational Technology, 48(3), 45-49.

Rodriguez-Valls, F., \& Ponce, G. (2013). Classroom, the We Space: Developing Student-Centered Practices for Second Language Learner (SLL) Students. Education Policy Analysis Archives, 21(55), 1-19.

Salinas, M. F., \& Johanna, G. (2008). Effect of Learner-Centered Education on the Academic Outcomes of Minority Groups. Journal of Instructional Psychology, 36(3), 226-237.

Saulnier, B. M., Landry, J. P., Longenecker, H. E., \& Wagner, T. A. (2009). From Teaching to Learning: Learner-Centered Teaching and Assessment in Information Systems Education. Journal of Information Systems Education, 19(2), 169-174.

Steckol, K. F. (2007). Learner-Centered Teaching in Higher Education: Formative Assessment Study Turns Classroom into Research Lab. The ASHA Leader, 12(5), 14-15.

Strobel, J., \& Van Barneveld, A. (2009). When is PBL More Effective? A meta-Analysis of Meta-Analyses Comparing PBL to Conventional Classrooms. The Interdisciplinary Journal of Problem-based Learning, 3(1), 44-58. http://dx.doi.org/10.7771/1541-5015.1046

Tomlinson, C. A., \& McTighe, J. (2006). Integrating Differentiated Instruction \& Understanding by Design: Connecting Content and Kids. Alexandria, VA: Association for Supervision \& Curriculum Development.

Weimer, M. (2002). Learner-Centered Teaching: Five Key Changes to Practice. San Francisco: Jossey-Bass.

Wells, M. A., \& Jones, B. D. (2005). Commonsense ISD: An Empirical Approach to Teaching Systems Analysis and Design. Conferences in Research and Practice in Information Technology, 42.

Wohlfarth, D., Sheras, D., Bennett, J. L., Simon, B., Pimentel, J. H., \& Gabel, L. E. (2008). Students Perceptions of Learner-Centered Teaching. Insight: Journal of Scholarly Teaching, 3, 67-74.

Yilmaz, K. (2008). Social Studies Teachers' Views of Learner-Centered Instruction. European Journal of 
Teacher Education, 31(1), 35-53. http://dx.doi.org/10.1080/02619760701845008

\section{Appendix A}

\section{Dear colleagues,}

The researcher will carry out a study to examine the EFL teachers' perceptions and barriers of learner-centered instruction in the preparatory year at Taif University. For this purpose, the researcher seeks your points of view by filling out the questionnaire below.

Please note that your contribution will be used for research purposes only.

Your agreement is appreciated.

The researcher

Dr. Tha'er Tawalbeh

Key: A= Agree,

SA = Strongly Agree

$\mathbf{D}=$ Disagree

$\mathbf{S D}=$ Strongly Disagree

Part 1: Personal Information

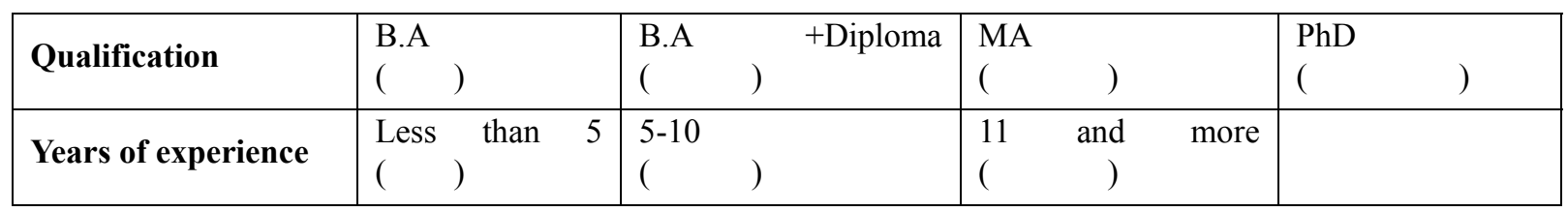

Part 2: Professional Information

\section{A-Teachers' Perceptions}

\section{Criteria}

\section{Degree}

\begin{tabular}{|c|c|c|c|c|c|}
\hline Criteria & & $\mathbf{A}$ & SA & D & SD \\
\hline 1 & $\begin{array}{l}\text { My job is to teach the material. If some students don't learn it, that is their } \\
\text { problem. }\end{array}$ & & & & \\
\hline 2 & Learner-centered approach requires too much work from me. & & & & \\
\hline 3 & Learner-centered approach is incompatible with my subject area. & & & & \\
\hline 4 & I have enough knowledge about learner-centered instruction. & & & & \\
\hline 5 & I want to learn more about learner-centered instruction. & & & & \\
\hline 6 & Learner-centered instruction is challenging but rewarding. & & & & \\
\hline 7 & Learner-centered approach diminishes the amount of content I can teach. & & & & \\
\hline 8 & Learner-centered approach is too time-consuming. & & & & \\
\hline 9 & I am a learner-centered teacher. & & & & \\
\hline 10 & $\begin{array}{l}\text { My students are passive and not always responsible. They are not ready } \\
\text { for learner-centered approach, in which they take responsibility for their } \\
\text { learning. }\end{array}$ & & & & \\
\hline
\end{tabular}




\section{B-Barriers of implementing learner-centered instruction}

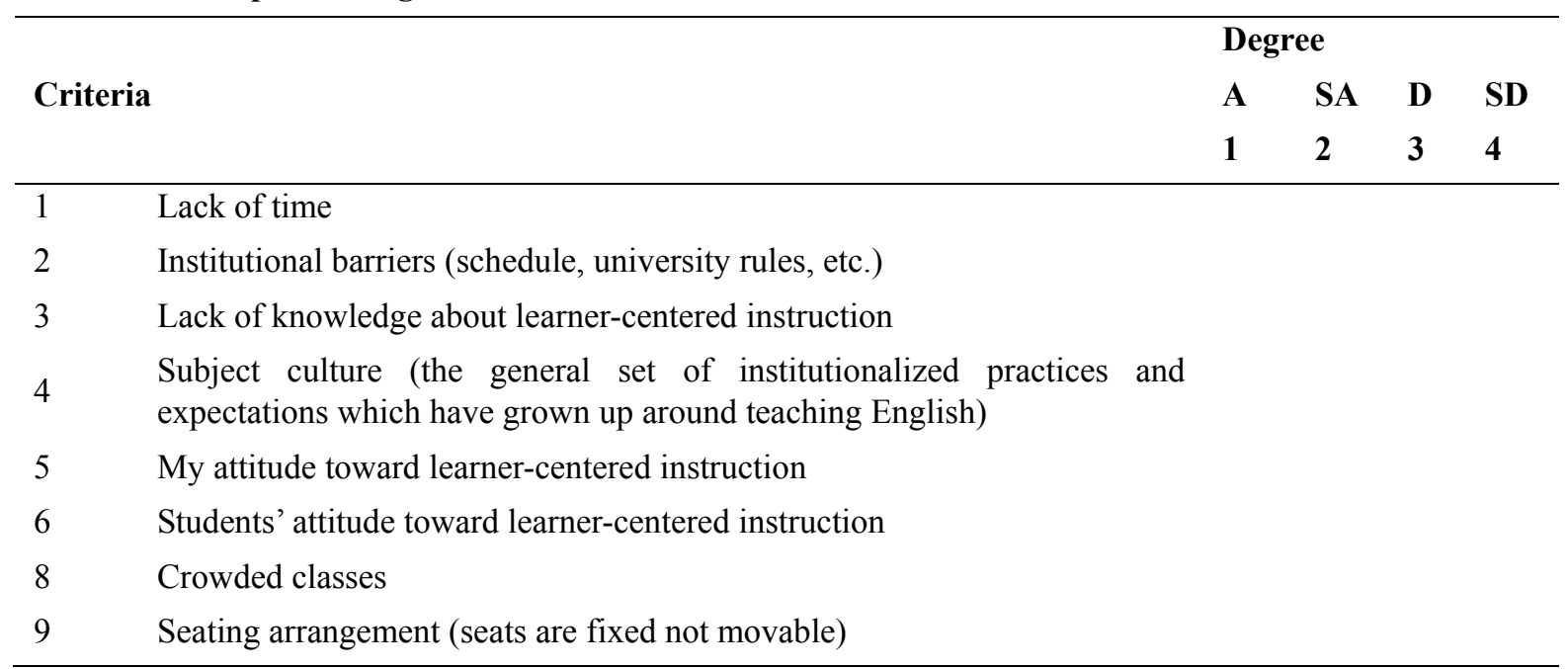

If you think there are other barriers to implementing learner-centered instruction, please write them down:

\section{Copyrights}

Copyright for this article is retained by the author(s), with first publication rights granted to the journal.

This is an open-access article distributed under the terms and conditions of the Creative Commons Attribution license (http://creativecommons.org/licenses/by/3.0/). 